\title{
若手アカデミーの動向
}

\section{第1回 若手科学者サミットの開催}

竹村仁美

2016年 7 月 10 日の午後、若手アカデミー (若手科学者ネットワーク分科会) が第 1 回若手科学者サミッ トを日本学術会議において開催した。若手科学者サミットは、若手の会組織間及び研究者個人間の学 術交流を目的として開催され、今回のサミットはポスター発表会の形式をとることとした。各学協会の 若手の会からポスターを募り、若手の会の紹介を中心に、紙面に余裕のある方については発表者個人 の研究も盛り込んだ内容を1枚のポスターにまとめて頂いた。

当日は午後 1 時より日本学術会議講堂で若手アカデミー（若手による学術の未来検討分科会）主催の シンポジウム「融合を問う：学問の消滅と生成の系譜学から」が開催されており、その途中から同時並 行の形で若手科学者サミットを開いた。午後 3 時 20 分、宇南山卓若手科学者ネットワーク分科会委員 長の開会の挨拶に続いて、自己紹介を兼ね、ポスター発表者全員が若手の会の紹介を含むフラッシュトー クを行った。折からの九州地方豪雨で道中、ポスターが湿気を含んでしまったといった小話が会場を沸 かせるなど、すべての参加者が他の若手の会の様子を熱心に聞き入った。

フラッシュトークを通じ、参加した多くの若手の会が産学又は産学官連携の形で活動している現状を 知り、また、活動頻度、活動経費、幹事の負担、若手研究者の減少といった共通の課題と対応策も見 えてきた。若手の定義に関して、多くの若手の会で厳密な年齢の上限を設定せず、「気持ちが若ければ 若手」「都市部と比べて地方部は若手研究者が少なく、若手の会の幹事には50代もいる」といった柔 軟な対応が見られることがわかった。ポスター発表会では、発表者と参加者との間で質疑応答もできて、 より具体的に若手の会の活発な活動内 容を知ることができた。顔に関する研 究を行う学会の若手の会は、化粧品会 社の職員も積極的に参加し、企業と学 術の交流の場となっている様子を話し てくださった。ポスター発表の個人研 究の内容は高度に専門的であり、いず れのポスターも力作で、参加者からは 次回から優れたポスターを表彰してほ しいとの声も上がった。若手の会が、

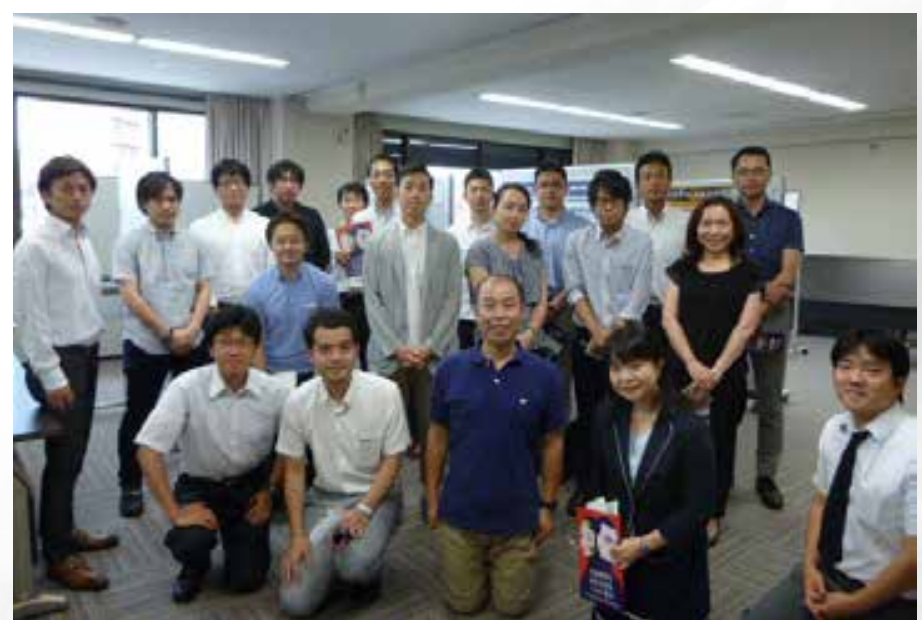


若手研究者と研究者を目指す大学院生相互間の成長・連携作用を促進し、時には産学官の協働・融合 の場を提供していることが明らかになったように思う。和気譪々とした䨌囲気の中、約 1 時間の発表時 間は瞬く間に流れ、名残惜しくも午後 4 時半前後に閉会となった。

今回、10の学協会の若手の会からポスター発表の応募があった。日本顔学会若手交流会、日本行 動科学学会若手の会、日本教育行政学会若手ネットワーク、日本心理学会若手の会、Japan National Young Water Professional、日本基礎心理学会若手研究者特別委員会、化学工学会九州支部若手エン ジニア連絡会、日本家禽学会若手幹事会、血管生物若手研究会、疫学の未来を語る若手の会（受付順） 以上の 10 の若手の会から 12 件のポスター発表の申込みがあり、当日 11 件の発表が行われた。

若手科学者サミットの招集に当たっては、若手アカデミーの前身組織である若手アカデミー委員会の 構築した若手科学者ネットワーク旧メーリングリストを主として活用した。現在、若手アカデミーとし て改めて新メーリングリストを準備中であることから、新メーリングリストへ新規登録申込みをしてく ださった方にもサミット開催を通知した。2016年7月中旬現在で、新メーリングリストの登録作業は進 行中であり、101の若手の会からメーリングリストへの参加の希望が出され、旧メーリングリストの 82 団体を上回っている。今後も若手科学者ネットワークの有意義で活発な利用を図りたい。

フプロフィール

竹村仁美（たけむら ひとみ）

日本学術会議特任連携会員、一橋大学大学院法学研究科准教授

専門：国際法

\section{若手アカデミー「国際分科会」の活動}

若手研究者の国際的なネットワーキングヘ向けて

北村友人

世界的に若手研究者を取り巻く環境は厳しさを増している。学位取得後も安定した研究職に就くこ とができないポストドクター問題は、多くの国で共通した課題となっている。また、不安定な環境のな かで成果主義がますます激しくなっているにもかかわらず、若手研究者のメンタル・ヘルスに関して十 分な注意が向けられているとはいえない。さらには、そうした状況のなかで研究倫理に反する行為へと 走る者も出てくる。 